\title{
The Elusive Quest for Digital Exhaustion in the US and the EU
}

\author{
The CJEU's Tom Kabinet Ruling a Milestone or Millstone for \\ Legal Evolution?
}

Shubha Ghosh \& Péter Mezei*

\begin{abstract}
The CJEU published its much-awaited preliminary ruling in Case C-263/18 Nederlands Uitgeversverbond and Groep Algemene Uitgevers (the Tom Kabinet case) in December 2019. Our paper aims to introduce the Tom Kabinet ruling and discuss its direct and indirect consequences in copyright law. The Tom Kabinet ruling has seriously limited (in fact, outruled) the resale of lawfully acquired ebooks. It left various questions unanswered, and thus missed the opportunity to provide for clarity and consistency in digital copyright law. Our analysis addresses how the CJEU deferred from its own logic developed in the UsedSoft decision on the resale of lawfully acquired computer programs, and how the CJEU's conservative approach ultimately missed the opportunity to reach a compromise ruling. The paper further introduces the US approach that has a strong distinction between selling and making with respect to the research of exhaustion. We aim to trace how this distinction rests on the statutory basis for exhaustion (in copyright) and common law basis (in patent and trademark law) and compare these findings with the CJEU's recent interpretation of exhaustion. Our focus will be on the Supreme Court's decisions in Kirstaeng and Bowman and lower court decisions that examine technological solutions to facilitate resale. We examine how the US approach adopts a rigid approach that might inhibit technological development in digital markets, an approach with parallels in the Tom Kabinet ruling. In conclusion, we assess whether there is convergence between the two sides of the Atlantic or whether there is a path of innovative legal development that reconciles the various precedents.
\end{abstract}

Keywords: digital exhaustion, Tom Kabinet, UsedSoft, ReDigi, copyright law.

* Shubha Ghosh: Crandall Melvin professor of law, Syracuse University, US. Péter Mezei: associate professor of law, University of Szeged; adjunct professor (dosentti), University of Turku, Finland. 


\section{Introduction}

The doctrine of exhaustion, more commonly referred to within the US as the 'first-sale' doctrine ${ }^{1}$ is one of the most fundamental principles of copyright law. Under this doctrine, the copyright holder must accept that copies, or the originals of copyrighted works, and other subject matter lawfully placed into circulation by or with the authorization of the rights holder, through sale or in any other form of transfer of ownership, are subsequently distributed by the lawful owner of those copies or originals, if the rights holder received proper remuneration for the initial distribution. ${ }^{2}$

The question of digital exhaustion came into the spotlight following the widespread online dissemination of individual copies of subject matter, e.g. software, sound recordings, movies or e-book. The CJEU published its UsedSoft ruling in 2012. The decision led to an instant turmoil in copyright law. The CJEU allowed for the online resale of computer programs lawfully purchased online, ${ }^{3}$ and hence applied the otherwise 'analogue' concept of exhaustion in the digital domain. Around the same time, by contrast, a US federal district court found against online resale in ReDigi regarding sound recordings. ${ }^{4}$ In the wake of these twin judgments, various other decisions - many of them originating from the CJEU - addressed the applicability of exhaustion in the online environment. ${ }^{5}$ The case-law of the CJEU looks like an exhausting dance exercise: more steps right, more steps left. The CJEU's most recent ruling in Tom Kabinet, we conclude in this article, does not convincingly solve the tensions surrounding digital exhaustion either.

We present our argument as follows. Section 2 introduces the facts of the Tom Kabinet case. Sections 3 and 4 summarize the opinion of the Advocate General and the judgment of the CJEU, respectively. Section 5 recalls four significant issues related to digital exhaustion, and Section 6 presents perspectives from the US. Therefore, Section 7 takes a critical look at the opinion and the judgment. As we believe that the ruling did not conclusively settle (and eliminate) the idea of digital exhaustion, we include various policy considerations in the final Section to support the need for a legal reform to extend the doctrine of exhaustion to the digital realm on a general level.

1 Exhaustion and first sale are referred to interchangeably. See Susy Frankel, 'Tangible Meets the Intangible: International Trade in Intellectual Property', in Jessica C. Lai \& Antoinette Maget Dominicé (eds.), Intellectual Property and Access to Im/material Goods, Edward Elgar, Cheltenham, 2016, p. 216.

2 Cf. Paul Goldstein \& P. Bernt Hugenholtz, International Copyright - Principles, Law and Practice, 2nd ed., Oxford University Press, Oxford, 2010, p. 305.

3 Judgment of 3 July 2012, Case C-128/11, UsedSoft, ECLI:EU:C:2012:407.

4 Capitol Records, LLC v. ReDigi Inc., 910 F.3d 649 (2018).

5 Péter Mezei, Copyright Exhaustion - Law and Policy in the United States and the European Union, Cambridge University Press, Cambridge, 2018, pp. 98-105. and 111-118; Caterina Sganga, 'A Plea for Digital Exhaustion in EU Copyright Law', JIPITEC, Vol. 9 (2019), Issue 3, pp. 224-227. 


\section{The Tom Kabinet Case}

Tom Kabinet was launched in the Netherlands in June 2014. The founders of Tom Kabinet allowed for private users to sell and purchase lawfully acquired DRM-free, 'used' e-books via the platform. ${ }^{6}$ Two publishing associations (Nederlandse Uitgeversbond/NUV and Groep Algemene Uitgevers/GAU) threatened the platform with a suit eight days after it started to operate in the Netherlands. The Associations deemed the service illegal, even though Tom Kabinet planned to keep 20 percent of the purchase price of each e-book sold through its system on an escrow fund for the benefit of the given authors. ${ }^{7}$

After an unsuccessful negotiation period, the Associations sued Tom Kabinet and requested preliminary injunctions against the website. The District Court of Amsterdam (Rechtbank Amsterdam) refused to order the preliminary injunctions, claiming that under UsedSoft it is not self-evident that the resale of used e-books is precluded under EU law. ${ }^{8}$ Joke Bodewits noted that

"A lot of emphasis was placed on the fact that Tom Kabinet adds a new watermark to the e-book after it has been purchased in an attempt to prevent trade in illegal copies. Although this may not be sufficient to prevent all illegal trade, the interim relief judge considered that further protective measures could not have been implemented without cooperation of the publishers. Moreover, the interim relief judge was clear that the behaviour of the publishers, by not replying to the invitation to discuss participation but instead initiating interim relief proceedings, was a step too far given the good intentions of Tom Kabinet."9

The Dutch Court of Appeals (Hof Amsterdam) upheld the Rechtbank Amsterdam's judgment; however, it prohibited Tom Kabinet from offering unlawfully downloaded e-books for sale. The court concluded that the application of UsedSoft on the resale of e-books could not be excluded per se. The online sale of contents fits into the concept of distribution, while the theory of functional equivalence stands for e-books too. Only a full trial can show whether Tom Kabinet's operation is in compliance with EU law. Nevertheless, the court believed that the plaintiff also allowed for the resale of illegal copies of e-books. The Hof

6 Nate Hoffelder, 'Used eBook Website Launches in Europe', The Digital Reader, 19 June 2014, at http://the-digital-reader.com/2014/06/19/used-ebook-website-launches-europe/.

7 Nate Hoffelder, 'Used eBook Website Faces Lawsuit in Europe', The Digital Reader, 27 June 2014, at http://the-digital-reader.com/2014/06/27/used-ebook-website-faces-lawsuit-europe/.

8 District Court of Amsterdam, Nederlands Uitgeversverbond and Groep Algemene Uitgevers v. Tom Kabinet, C/13/567567/KG ZA 14-795 SP/MV, 21 July 2014. See Nate Hoffelder, 'Publishers Lose First Round of Lawsuit against Used eBook Marketplace', The Digital Reader, 21 July 2014, at http://the-digitalreader.com/2014/07/21/publishers-lose-first-round-lawsuit-used-

ebookmarketplace/; Joke Bodewits, 'The Reselling of Second Hand E-Books Allowed in the Netherlands', E-Commerce Law Reports, 2014/4, pp. 10-11; Michel Olmedo Cuevas, 'Copyright: Dutch Copyright Succumbs to Aging as Exhaustion Extends to E-Books', Journal of Intellectual Property Law \& Practice, 2015/1, pp. 8-10.

9 Bodewits 2014, p. 11. 
Amsterdam took the view that the injunction might be dissolved if Tom Kabinet could demonstrate that its system is used solely for the resale of lawfully acquired e-books. ${ }^{10}$ No appeals were lodged on the Hof Amsterdam's legal conclusion. ${ }^{11}$

On 8 June 2015, Tom Kabinet switched its model and continued to operate as an e-book trader. The company purchased the used e-books either from official distributors or individuals who joined Tom Kabinet's reading club ('leesclub'), and Tom Kabinet sold the e-books to the registered members of the reading club. Tom Kabinet encouraged its clients to resell/donate the e-books to the company after they have read the works. When a client resold or donated an e-book to Tom Kabinet, the company granted 'credits' and, in case of donation, a 0.99 EUR discount on the monthly membership fee to the clients. The membership fee ceased to be a requirement from 18 November 2015. Tom Kabinet required its clients to erase the e-book from their devices simultaneously with the resale/ donation. Tom Kabinet also placed digital watermarks on all e-books to indicate the lawful nature of the given copies. ${ }^{12}$ It is uncertain, whether Tom Kabinet's service allowed for the simultaneous downloading of the same e-book by multiple members of the reading club or only individual members had access to the files. ${ }^{13}$

Based on the changes to Tom Kabinet's business model, NUV and GAU applied to the District Court of The Hague (Rechtbank Den Haag) for an injunction to prohibit Tom Kabinet from offering its services. The Rechtbank Den Haag found in its July 2017 interim injunction that e-books are works, and that Tom Kabinet's service did not constitute a communication to the public within the meaning of the InfoSoc-Directive. ${ }^{14}$ At the same time, the referring court was uncertain, whether the right of distribution as well as the doctrine of exhaustion

10 Court of Appeal of Amsterdam, Nederlands Uitgeversverbond and Groep Algemene Uitgevers v. Tom Kabinet, 200154 572/01 SKG 20-01-2015, NL:GHAMS:2015:66, available in Dutch at https:// uitspraken.rechtspraak.nl/inziendocument?id=ECLI:NL:GHAMS:2015:66. See the English translation of the decision in Computer Review International, 2015/2, pp. 47-50. See further Michel Olmedo Cuevas, 'Hot News: Amsterdam Court of Appeal Gives Tom Kabinet Three Days to Shut Down', The 1709 Blog, 20 January 2015, at http://the1709blog.blogspot.co.uk/2015/01/ hot-news-amsterdam-court-of-appeal.html; Saba Sluiter. 'The Dutch Courts Apply UsedSoft to the Resale of eBooks', Kluwer Copyright Blog, 28 January 2015, at http:// kluwercopyrightblog.com/2015/01/28/the-dutch-courts-apply-usedsoft-to-the-resale-ofebooks/; Lothar Determann, 'Digital Exhaustion: New Law From the Old World', Berkeley Technology Law Journal, 2018, p. 210; Sganga 2018, pp. 214-215.

11 Cf. Opinion of Advocate General Szpunar delivered on 10 September 2019 (AG Opinion), Case C-263/18, Nederlands Uitgeversverbond and Groep Algemene Uitgevers (Tom Kabinet), ECLI:EU:C: 2019:697, para. 19; Judgment of 19 December 2019, Case C-263/18, Tom Kabinet, ECLI:EU:C: 2019:1111, para. 23.

12 Cf. Case C-263/18, AG Opinion, para. 18; Case C-263/18, Tom Kabinet, paras. 22-26.

13 Cf. Id. para. 69 with Ansgar Ohly, "Anmerkungen zur "Öffentliche Wiedergabe" durch Verkauf "gebrauchter" E-Books - NUV ua/Tom Kabinet', Gewerblicher Rechtsschutz und Urheberrecht, Heft 2/2020, p. 184; Philipp Homar, 'Unzulässigkeit der Weiterveräußerung von E-Books Schlussfolgerungen aus EuGH C-263/18 - Tom Kabinet', MR-Int: Internationale Rundschau zum Medienrecht, IP-\&IT-Recht, 2020/1, pp. 29-30.

14 Cf. Article 3 of the Directive 2001/29/EC of the European Parliament and of the Council of 22 May 2001 on the harmonization of certain aspects of copyright and related rights in the information society. 
applies to the instant case. ${ }^{15}$ Likewise, the court was uncertain whether Tom Kabinet's service also necessitates the exhaustion of the (inherent) right of reproduction. ${ }^{16}$ In other words, the court was uncertain about the 'new copy theory. ${ }^{17}$ The Rechtbank Den Haag thus referred four questions to the CJEU. ${ }^{18}$

\section{Advocate General Szpunar's Opinion}

Advocate General (AG) Szpunar's opinion was constructed along three parts. He discussed the relevant norms (the legislative status quo), then the CJEU case-law, and finally policy considerations ('balancing the interests involved'). While AG Szpunar showed sympathy towards digital exhaustion, he ultimately refused the concept under all three rationales.

Regarding the status quo of exhaustion in the EU, AG Szpunar's starting point was that the WCT's umbrella solution prioritized the communication to the public right over the right of distribution regarding the dissemination of immaterial copies over the Internet. AG Szpunar admitted that the reality of markets has changed a lot since 1996 (adoption of WCT) and 2001 (enactment of the InfoSoc-Directive), while e-commerce has blurred the distinction between goods and services. ${ }^{19}$ Nonetheless, he concluded that European legislation clearly followed WCT's logic, which is evidenced by the language of the InfoSocDirective's recitals. ${ }^{20}$

AG Szpunar doubted that Article 4 of the InfoSoc-Directive applies to the online supply of digital content, as such materials are not subject to ownership interests. ${ }^{21} \mathrm{He}$ also questioned whether exhaustion could limit contractual freedom. ${ }^{22}$ AG Szpunar also took a bright-line position based on the creation of a 'new copy'. He opined that reproduction is not allowed for end-users except when they download the file originally. ${ }^{23}$ He further pointed out that no limitations and exceptions apply to the reproduction of new copies. ${ }^{24}$

AG Szpunar also discussed a limited list of CJEU rulings. Unsurprisingly, UsedSoft was analyzed in detail. ${ }^{25}$ AG Szpunar accepted the CJEU's position regarding the existence of a digital exhaustion doctrine regarding computer programs. He argued that the requirement of loading software to hardware as well as the need for updates/maintenance forced the CJEU to call the acquisition of a computer program as 'sale'. Based on these two features he concluded that tangible and intangible copies of computer programs are functionally equivalent.

Cf. Article 4(1) and (2) of the InfoSoc-Directive, respectively.

Cf. Article 2 of the InfoSoc-Directive.

Case C-263/18, AG Opinion, para. 20; Case C-263/18, Tom Kabinet, paras. 27-29.

Case C-263/18, AG Opinion, para. 21; Case C-263/18, Tom Kabinet, para. 30.

Case C-263/18, AG Opinion, paras. 35 and 38.

Id. paras. 33-39.

Id. para. 43 .

Id. para. 44

Id. paras. $45-48$.

Id.

Id. paras. 53-67. 
He refused to arrive at the same conclusion in respect of other subject matters. ${ }^{26}$ Second, AG Szpunar believed that the market for subject matters other than software is more fragile. ${ }^{27}$

AG Szpunar also recalled the CJEU's position that lending of e-books necessitates at least an indirect or limited digital exhaustion. In Vereniging Openbare Bibliotheken, the CJEU ruled that Member States are not precluded

"from making the application of Article 6(1) of Directive 2006/115 subject to the condition that the digital copy of a book made available by the public library must have been put into circulation by a first sale or other transfer of ownership of that copy in the European Union by the holder of the right of distribution to the public or with his consent, for the purpose of Article 4(2) of Directive [2001/29]."28

AG Szpunar agreed with Tom Kabinet that this ruling would become meaningless without the application of digital exhaustion regarding the immaterial copies acquired by the libraries. ${ }^{29}$

Finally, the Advocate General revisited the CJEU's case-law on linking. The Svensson ruling ${ }^{30}$ has led to intense debates whether communication to the public might be exhausted after the first making available to the public of protected subject matter where any future use is executed with the same technological means and Internet users do not form a 'new' public. ${ }^{31}$ This discussion might be naive in the light of the InfoSoc-Directive's language that expressly denies the applicability of exhaustion to this right. ${ }^{32}$ The importance of such discussion is, however, not superficial at all. Svensson's outcome represents nothing else than what exhaustion actually means: the loss of control of the use of the subject matter after the first lawful use by the rights holder. And vice versa: if the communication to the public right is not 'quasi-exhausted', what does Svensson really mean? The Advocate General solved the Gordian knot by noting that "that case-law cannot be applied by analogy to the making available of works to the public by downloading". 33

Id. paras. 58-60.

Id. para. 62.

Judgment of 10 November 2016, Case C-174/15, Vereniging Openbare Bibliotheken, ECLI:EU:C: 2016:856, para. 2 of the operative part, cited in Case C-263/18, AG Opinion, para. 71. Id.

Judgment of 13 February 2014, Case C-466/12, Svensson and others, ECLI:EU:C:2014:76.

On relevant literature see Case C-263/18, AG Opinion, note 55. See further Gregor Völtz, 'Das Kriterium der "neuen Öffentlichkeit” im Urheberrecht', Computer und Recht, 2014/11, pp. 721-726; Péter Mezei, 'Enter the Matrix: the Effects of the CJEU's Case Law on Linking and Beyond', Gewerblicher Rechtsschutz und Urheberrecht Internationaler Teil, 2016/10, pp. 887-900; João Pedro Quintais, 'Untangling the Hyperlinking Web: In Search of the Online Right of Communication to the Public', The Journal of World Intellectual Property, 2018/5, pp. 385-420; Giancarlo Frosio, 'It's All Linked: How Communication to the Public Affects Internet Architecture', Computer Law \& Security Review, Vol. 37, July 2020, Article 105410.

Article 3(3) of the InfoSoc-Directive.

Case C-263/18, AG Opinion, para. 74. 
The third prong of the Advocate General's analysis centered on the policy arguments related to digital exhaustion. At this point, AG Szpunar provided for a balanced list of various policy considerations. On the one hand, exhaustion might strengthen competition; lead to more innovation; guarantee privacy; and prevent anti-competitive practices. On the other hand, digital copies do not deteriorate; the multiplication of works may pose a risk to competition, it is difficult to verify compliance with rules; especially among end-users; it might be difficult to differentiate between lawful and illegal copies; and the whole idea of exhaustion might become obsolete in the wake (and, in fact, by the dominance) of streaming services. ${ }^{34}$ Based on the various conflicting policy considerations, AG Szpunar took a rather defensive position and concluded that the conflicting policy arguments does not allow for overruling the rules in force. ${ }^{35}$

\section{The CJEU's Judgment}

Contrary to the detailed opinion of the Advocate General, the CJEU's judgment was almost entirely based on the historic, teleological and systematic analysis of the relevant legal sources. The CJEU noted that the InfoSoc-Directive's language is unclear as to whether the supply by downloading, for permanent use, of ebooks is covered by the right of communication to the public or the right of distribution. ${ }^{36}$ The CJEU argued that the travaux préparatoires and the recitals of the InfoSoc-Directive, as well as the WCT support the conclusion that the right of distribution covers solely the transfer of ownership of tangible copies of works; while the right of communication to the public covers interactive/on-demand dissemination of copies in the broadest sense. ${ }^{37}$

The CJEU excluded e-books from the scope of the Software Directive. Indeed, in compliance with the Nintendo ruling, ${ }^{38}$ even if an e-book would comprise software, such a program would be incidental in relation to the literary work, and hence the InfoSoc-Directive would trump the Software Directive. ${ }^{39}$ The CJEU also refused to apply the theory of functional equivalence to e-books. The CJEU agreed with the Advocate General that e-books are perfect substitutes of the original copies, they do not deteriorate with age, no additional efforts or costs are needed for the resale of copies, and hence "a parallel second-hand market would be likely to affect the interests of the copyright holders in obtaining appropriate reward for their works". 40

Finally, the CJEU discussed the meaning of communication and making available to the public in details. Communication has always been interpreted broadly by the CJEU, and the public has been defined as an indeterminate, but 
certainly large number of people. Successive recipients of contents form a public as well, that is, potential recipients shall be accumulated. ${ }^{41}$ The CJEU found that Tom Kabinet's service complied with all relevant prerequisites of communication to the public. ${ }^{42}$ The CJEU concluded that members of the reading club represent a 'new public', that is, members of the public who were not taken into account when the e-books were originally sold by the rights holders. ${ }^{43}$

\section{Revisiting the Critical Points of Digital Exhaustion}

Before turning to the critical analysis of the opinion and the judgment, we shall revisit the most important doctrinal and practical aspects of digital exhaustion. We shall address the license versus sale dichotomy; whether the transfer of digital contents via the Internet fits into the right of distribution or making available to the public; the transfer (migration) of digital copies via the Internet; as well as the issues of lex specialis and the theory of functional equivalence. ${ }^{44}$

\subsection{License Versus Sale}

In UsedSoft, the CJEU concluded that a license may be characterized as a sale if the right to use a computer program lasts for an indefinite period "in return for payment of a fee designed to enable the copyright holder to obtain a remuneration corresponding to the economic value of the copy of the work of which he is the proprietor". ${ }^{45}$ Merely calling a contract a license is not enough "to circumvent the rule of exhaustion and divest it of all scope". 46

Although the CJEU's judgment has received some criticism, ${ }^{47}$ the CJEU did not limit the freedom of rights holders to negotiate the value of their rights. It actually said that the right of distribution is exhausted as soon as the protected subject matter is put into circulation by or with the consent of the right holder in exchange for a reasonable remuneration. ${ }^{48}$ Here, the CJEU relied on the core/ history policy basis of exhaustion, namely, the reward theory.

Furthermore, the CJEU defined sale as the transfer of ownership rights in tangibles or intangibles. ${ }^{49}$ Such a right lacks merit in several legal systems, e.g. in

41 Id. para. 68. On the concept of communication to the public see e.g. Bernd Justin Jütte, 'Ein horizontales Konzept der Öffentlichkeit - Facetten aus dem europäischen Urheberrecht', UFITA - Archiv für Medienrecht und Medienwissenschaft, 2018/2, pp. 354-374. Case C-263/18, Tom Kabinet, para. 69. Id. paras. $70-71$.

44 Three of these critical points were thoroughly addressed in Sganga 2018, pp. 217-222.

45 C-128/11, UsedSoft, para. 49.

46 Id.

47 Christopher Stothers, 'When is Copyright Exhausted by a Software Licence? UsedSoft v. Oracle', European Intellectual Property Review, 2012/11, p. 790.

48 In its FAPL ruling, the CJEU noted that rights holders might demand reasonable remuneration rather than "the highest possible remuneration." See Judgment of 4 October 2011, Joined Cases C-403/08 and C-429/08, Football Association Premier League and others, ECLI:EU:C:2011:631, para. 108. 
Germany, where property rights only exist over tangibles. ${ }^{50}$ By contrast, property interests exist on intangibles in Austria, ${ }^{51}$ in the Netherlands, ${ }^{52}$ or in Canada. ${ }^{53}$ German, ${ }^{54}$ Austrian ${ }^{55}$ and Dutch ${ }^{56}$ courts also decided that computer programs can be sold without the transfer of ownership over the intangible data incorporated in the software. On the other hand, German courts refused to apply the doctrine of exhaustion to the transfer of audiobooks on the ground that no ownership interests exist on digital data, e.g. a file of an audiobook. ${ }^{57}$

It has been very hard to find a compromise in this question. Indeed, the best solution might be not to limit the available legal options to only license/service and sale. Such a flexible solution was outlined in the (since then abandoned) Proposal for a Regulation on the Common European Sales Law. Besides sales and service contracts, Article 5(b) proposed a hybrid type of contract:

"contracts for the supply of digital content whether or not supplied on a tangible medium which can be stored, processed or accessed, and re-used by the user, irrespective of whether the digital content is supplied in exchange for the payment of a price." 58

The Commission did not discuss whether and how the doctrine of exhaustion could have been applied to such hybrid contracts. In copyright terms such

50 Helmut Haberstumpf, 'Der Handel mit gebrauchter Software im harmonisierten Urheberrecht Warum der Ansatz des EuGH einen falschen Weg zeigt', Computer und Recht, 2012/9, pp. 562-567; Herbert Zech, 'Vom Buch zur Cloud - Die Verkehrsfähigkeit digitaler Güter', Zeitschrift für Geistiges Eigentum / Intellectual Property Journal, 2013/3, pp. 375-381.

51 Friedrich Ruffler, 'Is Trading in Used Software an Infringement of Copyright? The Perspective of European Law', European Intellectual Property Review, 2011/6, p. 378.

52 District Court Mid-Nederlands, CWS v. Vendorlink, ECLI:NL:RBMNE:2015:1096, 25 March 2015, paras. 60-62.

53 Pierre-Emmanuel Moyse, 'From Importation to Digital Exhaustion: A Canadian Copyright Perspective', in Irene Calboli \& Edward Lee (eds.), Research Handbook on Intellectual Property Exhaustion and Parallel Imports, Research Handbooks in Intellectual Property, Edward Elgar, Cheltenham, 2016, p. 489.

54 BGH 22 December 1999 (VIII ZR 299/98) - Ablieferung von Standard-Software, JurPC Web-Dok. 70/2000, Abs. 1-26, at www.jurpc.de/jurpc/show?id=20000070; BGH 15 November 2006 (XII ZR 120/04) - 'Zur Rechtsnatur der Softwareüberlassung im Rahmen eines ASP-Vertrages', Medien Internet und Recht, 2007/1, p. 3, at http://medien-internet-und-recht.de/pdf/vt_MIR_Dok_0092006.pdf.

55 OGH 23 May 20004 Ob 30/00s, Medien und Recht, 2000/4, pp. 249-253; see further Clemens Appl \& Marlene Schmidt, 'Zweitverwertung gebrauchter Digitalgüter - Die Folgen des UsedSoftUrteils für Schöpfungen anderer Werkarten', Medien und Recht, 2014/4, p. 192.

56 Dutch Supreme Court, Beeldbrigade, ECLI:NL:HR:2012:BV1301, 27 April 2012, Computerrecht, 2012/2, pp. 339-353.

57 OLG Stuttgart 03 November 2011 (2 U 49/11) - 'Keine Erschöpfung bei Online-Vertrieb von Hörbüchern', Computer und Recht, 2012/5, p. 351; OLG Hamm 15 May 2014 (22 U 60/13) 'Keine Erschöpfung bei Audiodateien - Hörbuch-AGB', Gewerblicher Rechtsschutz und Urheberrecht, 2014/9, pp. 861-862.

58 Proposal for a Regulation of the European Parliament and of the Council on a Common European Sales Law, COM(2011) 635 final, Brussels, 10 November 2011, p. 27. Cf. Zech 2013, pp. 386-387; Stojan Arnerstål, 'Licensing Digital Content in a Sale of Goods Context', Journal of Intellectual Property Law and Practice, 2015/10, p. 753. 
contracts would fit best in the right of distribution, and hence they could be subject to the doctrine of exhaustion, too. ${ }^{59}$ More importantly, the EU's Directive $2019 / 770$ on certain aspects concerning the contracts for the supply of digital content and digital services did not follow such a flexible idea. This directive clearly left EU copyright acquis - including the InfoSoc-Directive - untouched. ${ }^{60}$

Directive 2011/83/EU on consumer rights was more successful in finding a compromise. The Directive expressly notes that contracts for digital content, ${ }^{61}$ which are not supplied on a tangible medium, should be classified neither as sales contracts, nor as service contracts. ${ }^{62}$ Although the Directive leaves intact all other norms of the EU, including the rules on the right of distribution and the doctrine of exhaustion, it can serve as a good starting point for a more consumer-centric regime. ${ }^{63}$

In sum: reasonable arguments support the view that the online supply of data should be treated as a special type of contract. The question that needs to be addressed at this point is whether such contract shall be covered by the right of distribution or communication (making available) to the public.

\subsection{Distribution Versus Making Available to the Public}

It may be worth recalling that the right of distribution was historically designed to cover the transfer of ownership of tangible copies, and the making available to the public right was designed to cover on-demand uses.

In UsedSoft, the CJEU affirmed that a data transfer via the Internet can fit into the making available to the public right. Nevertheless, the CJEU found the transfer of ownership of a copy of a computer program to be a first sale, which changed an act of communication to the public into an act of distribution. ${ }^{64}$ In this sense, the CJEU differentiated between two types of uses via the Internet. In the first scenario, uses that do not lead to the permanent reproduction or sale of any copy of a protected subject matter are governed by the communication or making available to the public right. In the second scenario, a permanent copy is

59 Lazaros G. Grigoriadis, "The Distribution of Software in the European Union after the Decision of the CJEU “UsedSoft GmbH v. Oracle International Corp." ("UsedSoft")', Journal of International Commercial Law and Technology, 2013/3, p. 202.

60 Directive (EU) 2019/770 of the European Parliament and of the Council of 20 May 2019 on certain aspects concerning contracts for the supply of digital content and digital services, recital 36 and Article 3(9). See further Franz Hofmann, 'Recht der digitalen Güter: Keine digitale Erschöpfung bei der Weitergabe von E-Books - Anmerkung zu EuGH', Urteil vom 19.12.2019 C-263/18 - NUV u. a./Tom Kabinet Internet u. a. (ZUM 2020, 129)', Zeitschrift für Urheber- und Medienrecht, 2020/2, p. 138.

61 “'Digital content' means data which are produced and supplied in digital form." See Consumer Rights Directive, Article 2(11). Digital contents are e.g. "computer programs, applications, games, music, videos or texts, irrespective of whether they are accessed through downloading or streaming, from a tangible medium or through any other means." Id. Recital 19.

62 Id.

63 Stazi 2012, p. 171. To the contrary, Lothar Determann argues that "from a consumer welfare perspective, courts and legislatures should respect contract terms and commercial transaction types, as U.S. courts generally have, and as German courts have with respect to digital goods other than software", see Determann 2018, p. 219. 
received by the end user in exchange for a fixed purchase price and is retained on a permanent basis. The CJEU classified this second category of uses as sale of products, which is covered by the right of distribution. ${ }^{65}$

It is interesting to compare the wording of the making available to the public right and the business models of UsedSoft or Tom Kabinet. That right is formulated as follows:

"making available to the public of their [works/phonograms/performances fixed in phonograms] in such a way that members of the public may access these [works/phonograms/performances fixed in phonograms] from a place and at a time individually chosen by them." 66

Although the business models of the respective companies are generally available to any member of the public, access to a specific content is conditional. One important obstacle hampers users from accessing the contents "from a place and at a time individually chosen by them". They need to accept the terms of the sale, by purchasing the subject matter under specific conditions. ${ }^{67}$ Ultimately, access to protected subject matter is not on-demand but "pay-walled". In such situations the (broad or unlimited) application of the right of making available to the public seems unconvincing. ${ }^{68}$ The Supreme Court of Canada followed a very similar approach in ESA. There, the Court concluded that the downloading of a videogame, which included a protected musical work, did not amount to public communication, but represented a functional equivalent of the purchase of a data carrier in a brick-and-mortar store. ${ }^{69}$

The rethinking of economic rights in the Internet age may become necessary. This has been perfectly reflected by the draft Common European Sales Law and the Directive on consumer rights. The concept of the contract for the supply of digital contents is a balanced approach in contract law, which attempts to regulate digital transactions that cannot be easily fit into sales and service-type

Some commentators criticized the above logic, e.g. Thomas Vinje et al., 'Software Licensing after Oracle v. UsedSoft - Implications of Oracle v. UsedSoft (C-128/11) for European Copyright Law', Computer Law Review International, 2012/4, p. 100; Emma Linklater, 'UsedSoft and the Big Bang Theory: Is the e-Exhaustion Meteor about to Strike?', JIPITEC, Issue 1/2014, p. 15; Ole-Andreas Rognstad, 'Legally Flawed but Politically Sound? Digital Exhaustion of Copyright in Europe after UsedSoft', Oslo Law Review, 2014/1, p. 15. Others applauded it, e.g. Martin Senftleben, 'Die Fortschreibung des urheberrechtlichen Erschöpfungsgrundsatzes im digitalen Umfeld', Neue Juristische Wochenschrift, 2012/40, p. 2926; Grigoriadis 2013, p. 203.

66 WCT Article 10, WPPT Article 14, InfoSoc-Directive Article 3(1) and 3(2)(c)-(d).

67 Cf. Alexandra Morgan et al., 'ECJ Rules that the Sale of Second-hand e-Books Infringes Copyright', Journal of Intellectual Property Law \& Practice, 2020/4, p. 238.

68 Id.

69 "In our view, there is no practical difference between buying a durable copy of the work in a store, receiving a copy in the mail, or downloading an identical copy using the Internet. The Internet is simply a technological taxi that delivers a durable copy of the same work to the end user." See Entertainment Software Association v. Society of Composers, Authors and Music Publishers of Canada, 2012 SCC 34, [2012] 2 R.C.S. 231, para. 5. 
contracts. Copyright law should also classify this type of contract and the right of distribution seems to meet this demand the easiest.

\subsection{The New Copy Theory Versus Migration of Files and Forward-and-Delete Technologies}

The copyright law of the EU and of the majority of the Member States allows for the private copying of works. This limitation of the reproduction right should not in any way lead to the expansion of the exhaustion doctrine. Exhaustion allows the lawful acquirer of a protected subject matter to resell 'the particular' copy he owns/possesses. The creation of a new copy excludes the applicability of the doctrine. Naturally, keeping a copy of a work after the resale of the originally acquired copy runs afoul of the private copying exception, as well as the doctrine of exhaustion. What can be of importance is the forwarding or migration of the copy from the original acquirer to a new user.

In UsedSoft, the CJEU noted that second and any subsequent acquirers of lawfully sold copies are lawful acquirers too. The reproduction of the computer program by these subsequent acquirers is equally necessary to enable the use of the software in accordance with its intended purpose. ${ }^{70}$ By contrast, the doctrine of exhaustion was excluded in the German audiobook cases in line with the 'new copy theory'. ${ }^{71}$

Although these opinions were based on the logical interpretation of the then effective copyright norms, they are a far cry from reality in several cases. It is true that media contents can be directly downloaded to portable devices. Average users, who are absolute strangers to the subtle nuances of copyright law, quite often download the content first to their computer's hard drive and reproduce the file on any device thereafter. Sometimes they first move the file to another folder of the computer. Some devices need to be connected to a computer first, in order to synchronize the device and the user's account. In short, all portable devices might carry copies of digital contents that are certainly not those particular original copies. ${ }^{72}$

All of these concerns lead us to the migration of files and forward-and-delete technologies. Although their effectiveness is often questioned, ${ }^{73}$ these concerns are superficial. There have been no technologies (neither analogue, nor digital) that have been able to perfectly control the use of protected subject matter. The introduction of digital rights management or technological protection measures remained unsuccessful in most fields of the copyright industry. ${ }^{74}$ Indeed, there

C-128/11, UsedSoft, paras. 80-81.

OLG Stuttgart (2011) 301; OLG Hamm (2014) 855-857. Cf. Determann 2018, pp. 198-203.

B. Makoa Kawabata, 'Unresolved Textual Tension: Capitol Records v. ReDigi and a Digital First Sale Doctrine', UCLA Entertainment Law Review, Winter 2014, pp. 75-76.

73 OLG Stuttgart (2011) 302; Capitol Records, LLC, v. ReDigi Inc., 934 F.Supp.2d 640 (2013), pp. 650-651. See further Evan Hess, 'Code-ifying Copyright: An Architectural Solution to Digitally Expanding the First Sale Doctrine’, Fordham Law Review, March 2013, pp. 2001-2011.

Peter K. Yu, 'Anticircumvention and Anti-Anticircumvention', Denver University Law Review, 2006/1, pp. 13-77. 
are several notable forward-and-delete technologies (some of them patented) that allow for a technologically effective control over the transfer or 'aging' of data. ${ }^{75}$

We agree with Dennis Karjala, who noted that

"Whether erasure takes place immediately after transfer or whether the transfer takes place one byte at a time with erasure occurring as part of the ongoing process makes no difference to the end result or to the position of the copyright owner once the process has finished. Yet, if the byte-by-byte process, including erasure, is deemed the making of an unauthorized copy, the first-sale doctrine is for all practical purposes a dead letter in the digital age."76

5.4. Different Subject Matters, Lex Specialis, and the Theory of Functional Equivalence UsedSoft raised another notable question: is the Software-Directive special law (lex specialis) regarding the doctrine of exhaustion?

Historically, international and domestic copyright norms have expressly opted for the protection of computer programs as literary works under copyright law, rather than granting sui generis protection for them. ${ }^{77}$ The EU's Software Directive shows some differences when compared to the rules on literary works. One of these differences is that the Software Directive does not differentiate between tangible and intangible copies of computer programs regarding the doctrine of exhaustion. By contrast, under the InfoSoc-Directive, solely tangible objects are subject to the doctrine. The CJEU correctly noted that

"From an economic point of view, the sale of a computer program on $C D$ ROM or DVD and the sale of a program by downloading from the internet are similar. The online transmission method is the functional equivalent of the supply of a material medium." ${ }^{\text {78 }}$

This argument holds true also from a technological point of view. The creation of a copy of the software on the computer is inevitable and therefore lawful. ${ }^{79}$ Yet, the above logic is partially flawed. According to the CJEU,

"interpreting Article 4(2) of Directive 2009/24 in the light of the principle of equal treatment confirms that the exhaustion of the distribution right under

76 Dennis S. Karjala, “'Copying” and "Piracy” in the Digital Age', Washburn Law Journal, Spring 2013, p. 255. See further Giorgio Spedicato, 'Online Exhaustion and the Boundaries of Interpretation', in Roberto Caso \& Federica Giovanella (eds.), Balancing Copyright Law in the Digital Age Comparative Perspectives, Springer, Berlin, 2015, p. 56.

77 Article 10 TRIPS; Article 4 WCT. See further Article 1(1) of the Directive 2009/24/EC of the European Parliament and of the Council of 23 April 2009 on the legal protection of computer programs (Codified version). The definition of literary works is covered by Article 1(1) of the Berne Convention.

78 C-128/11, UsedSoft, para. 61.

79 Cf. Article 5(1) of the Software Directive. 
that provision takes effect after the first sale in the European Union of a copy of a computer program by the copyright holder or with his consent, regardless of whether the sale relates to a tangible or an intangible copy of the program." 80

The CJEU either "'purposely' construed the law to arrive at this outcome" 81 or made a mistake when it disregarded the relevant Agreed Statement of the WCT. The WCT did not provide any specific right of distribution or exhaustion for computer programs, hence, the general rules should prevail for software as well. The right of distribution represents a minimum right under the WCT and therefore signatories can only provide for stronger protection to rights holders. ${ }^{82}$

Arguments to the effect that the Agreed Statement to Article 6 of the WCT does not apply to computer programs, because the Council introduced the Software Directive before the WCT was accepted, and so the directive became lex specialis, are misleading. The EU implemented the WCT through the InfoSocDirective. ${ }^{83}$ This directive harmonized a general right of distribution and a general exhaustion doctrine without making any reference to different subject matters. The InfoSoc-Directive left the "specific provisions on protection provided for by Directive 91/250/EEC" intact. ${ }^{84}$ At the same time,

"This Directive is based on principles and rules already laid down in the Directives currently in force in this area, in particular Directives 91/250/EEC [...], and it develops those principles and rules and places them in the context of the information society. The provisions of this Directive should be without prejudice to the provisions of those Directives, unless otherwise provided in this Directive." 85

Recital 29 of the InfoSoc-Directive seems to be such an other provision. As a result, the special application of the doctrine of exhaustion to computer programs sold in intangible format runs afoul to the existing rules of international and EU copyright law. ${ }^{86}$

The Parliament and the Council codified the Software Directive in 2009. The fact that the Agreed Statement to Article 6 of the WCT was not transposed by the

81 Ellen Franziska Schulze, 'Resale of Digital Content Such as Music, Films or eBooks under European Law', European Intellectual Property Review, 2014/1, p. 11.

82 Silke von Lewinski, International Copyright Law and Policy, Oxford University Press, New York, 2008, p. 452, para. 17.61; Eleonora Rosati, 'Online Copyright Exhaustion in a Post-Allposters World’, Journal of Intellectual Property Law \& Practice, 2015/9, p. 675.

83 InfoSoc-Directive, Recital 15.

84 Id. Recital 50 and Article 1(2)(a).

85 Id. Recital 20.

86 Rognstad 2014, pp. 9-10; Miha Trampuž, 'An Oracle on European Copyright Exhaustion', Revue Internationale du Droit d'Auteur, July 2016, pp. 201-203. See to the contrary Ruffler 2011, p. 379; Alexander Göbel, 'The Principle of Exhaustion and the Resale of Downloaded Software - The UsedSoft v. Oracle Case [UsedSoft GmbH v. Oracle International Corporation, ECJ (Grand Chamber), Judgment of 3 July 2012, C-128/11]', European Law Reporter, 2012/9, p. 230. 
directive is either the legislation's expressed intent or a mistake. In any case, it cannot allow for an assumption that EU law can sustain any special regulation on the resale of intangible copies of computer programs. The Software Directive was not amended in this respect, which also evidences the primacy of the InfoSocDirective. ${ }^{87}$ In his opinion in $V O B$, AG Szpunar argued that

"in accordance with the principle of terminological consistency, rigorously applied, the term 'copy' used in both Directive 2001/29 and Directive 2006/115 ought to be understood as including digital copies with no physical medium. That same principle would also afford a simple solution to the problem, widely debated by legal theoreticians and present also in this case, of the exhaustion of the distribution right following a sale by electronic data transmission. Indeed, Article 4(2) of Directive 2001/29 is formulated, in substance, in identical terms to Article 4(2) of Directive 2009/24 and consequently it ought, in principle, to be interpreted in identical fashion." 88

It should be an important task of the CJEU to preserve the consistency of terminology of the acquis and to safeguard the principle of equal treatment. What AG Szpunar recommended is that the interpretation of a special law shall determine the application of general norms as well. This seems to be a misunderstanding of the hierarchy of the EU copyright norms. ${ }^{89}$

Is the theory of functional equivalence applicable to subject matters other than computer programs? The CJEU argued that from an economic point of view, the online transmission of a computer program is functionally equivalent with the sale of a data carrier in a tangible format. If this is the case, one should conclude that the economic equivalence of sound recordings, audiobooks, and ebooks is different. The different types of use are clearly in competition with each other, as sound recordings, audiobooks, and e-books can all be marketed and used in different ways and they can be used on several different devices/platforms. The outcome is absolutely the same from a technological point of view. Sound recordings/audiobooks do not need to be permanently copied (installed) for the purpose of enjoyment. The online transmission method does not seem to be the functional equivalent of the supply of a material medium regarding subject mattes other than software. ${ }^{90} \mathrm{~A}$ similar conclusion can be drawn from a contextual interpretation of EU acquis. The Software Directive allows for the first reproduction of computer programs, if that is necessary for the proper

87 Cf. Thomas Hartmann, "Weiterverkauf und "Verleih" online vertriebener Inhalte - Zugleich Anmerkung zu EuGH, Urteil vom 3. Juli 2012, Rs. C-128/11 - UsedSoft./. Oracle', Gewerblicher Rechtsschutz und Urheberrecht Internationaler Teil, 2012/11, p. 982.

88 Case C-174/15, Vereniging Openbare Bibliotheken, Opinion of Advocate General Szpunar, delivered on 16 June 2016, ECLI:EU:C:2016:459, para. 52.

89 In its judgment the CJEU did not address the above argument of AG Szpunar.

90 See to the contrary Hartmann 2012, p. 982; Sven Schonhofen, 'UsedSoft and Its Aftermath: The Resale of Digital Content in the European Union', Wake Forest Journal of Business and Intellectual Property Law, 2015/2, p. 291. 
functioning of the software. ${ }^{91}$ Such an essential step defense ${ }^{92}$ does not exist regarding other subject matters, and it is indeed obsolete. ${ }^{93}$

In sum, terminological and doctrinal consistency is necessary when it comes to the doctrine of exhaustion. Under the current copyright status quo, WCT/ InfoSoc-Directive has a primacy over other sources of law, and digital exhaustion can hardly be based on these norms. The theory of functional equivalence supports such conclusion too.

\section{A Comparison With the Technological Approach in the US}

For US courts, digital technology poses two challenges for the application of the exhaustion doctrine. First, the immateriality of digital goods distinguishes them from traditional chattels. Alienability reflects in part the physicality of material goods and their transferability. Digital goods can be deleted readily and are more fungible than physical goods. They can be replicated and seem less subject to the scarcity limitations in producing physical goods. There can be enough copies to meet the demand of all consumers at relatively low cost. Technology can limit their distribution. Second, digital goods, sold through the medium of the Internet, are not limited by geographical boundaries. To speak of international, regional, or national exhaustion for markets on the Internet seems meaningless. Consequently, the terms of exhaustion are more troubling to negotiate and ascertain for Internet transactions. In short, digital goods create uncertainty for the traditional contours of the exhaustion doctrine.

What is particularly interesting about digital goods is the evolving question of the applicability of the exhaustion doctrine to e-books, as well as to digitized movies, and MP3's or and other digital music formats for music. The argument has been raised that exhaustion principles should limit intellectual property rights in the digital content. Specifically, advocates ${ }^{94}$ for purchasers of digital goods have argued that they should be allowed to resell the digital works under the exhaustion doctrine as an extension of the first sale doctrine in copyright law to digital works. ${ }^{95}$ The argument has not been successful in the US, but the litigation demonstrates how the exhaustion doctrine looms over emerging areas of intellectual property law.

Lower courts below the Supreme Court in the US have addressed issues of copyright exhaustion in response to particular industry practices, but the right to

91 Software Directive Article 5(1).

92 Under US copyright law (USC), the essential-step defense permits "the owner of a copy of a computer program to make [...] another copy [...] of that computer program provided [...] that such a new copy [...] is created as an essential step in the utilization of the computer program." See 17 USC $\S 117$ (a). The essential step doctrine allows a lawful owner of a computer program to copy the copyrighted code into memory when booting up the software for the licensed use. See discussion in MAI Sys. Corp. v. Peak Computer, Inc., 991 F.2d 511 (9th Cir. 1993) [statutorily overruled on the computer maintenance or repair ruling through 17 USC $§ 117(c)]$. Homar 2020, p. 29.

94 Aaron Perzanowski \& Jason Schultz, 'Digital Exhaustion', UCLA Law Review, 2011, pp. 889-946. 
resell digital content, that is, works subject to technology protection measures, is an ongoing issue. The one district court ruling against exhaustion of digital works, Capitol Records, LLC v. ReDigi, Inc., based its 2013 decision on the recopying of the technologically-protected work by the purchaser that was inherent in reselling it. ${ }^{96}$ According to the court, copyright exhaustion does not permit recopying the work because unlimited copying would lower the demand for the original work. However, the purchaser could resell the protected work as embodied in a physical medium (such as a digital player or a personal computer) as long as no new copies were made. The application of copyright exhaustion to digital works will be of continued importance as more content migrates to electronic formats. The Second Circuit affirmed largely on statutory grounds, reasoning that Congress had legislated the exhaustion doctrine in copyright law as a limitation on the distribution right, not the reproduction right. ${ }^{97}$

Digital works pose a challenge for the exhaustion doctrine across intellectual property regimes because digitization can be considered a type of self-replicating technology, as works can be copied perfectly and repeatedly. In the Bowman case, the US Court of Appeals for the Federal Circuit confronted this issue in the specific context of patent exhaustion for genetically modified seeds. The Federal Circuit concluded that since exhaustion could eviscerate patent protection for self-replicating technologies, the exhaustion doctrine should have limited applications for such technologies. ${ }^{98}$ The Supreme Court, however, in reviewing the Federal Circuit, rejected a separate rule of exhaustion for all self-replicating technologies. Instead, the Court affirmed the Federal Circuit's decision against exhaustion, stating that its ruling "is limited" to the particular facts of Bowman, namely exhaustion for patents in genetically modified seeds. As for other types of self-replicating technologies, such as those related to digital content, the Court hesitated to create a general rule because of the complexities of such technologies. As the Court stated, "the article's self-replication might occur outside the purchaser's control. Or it might be a necessary but incidental step in using the item for another purpose." 99 Therefore, the Supreme Court's decision leaves open the question of how the patent exhaustion doctrine (and perhaps other areas of exhaustion) might apply to other self-replicating and digital technologies.

Exhaustion rules may work differently for digital works than for analogue works, and the balance between the interests of intellectual property rights holders and those of users is still developing in the digital context. The current trend in the US for readily replicated works and technologies seems to favor rights holders at the expense of users, as affirmed by the Supreme Court's 
decision on patent exhaustion in Bowman. ${ }^{100}$ In general, the Court's distinction between using and making, the former permitted under exhaustion and the latter not, creates an obstacle for extending the protections accorded by the exhaustion doctrine to digital works. Reusing a digital work in the modern technological environment entails making a new version, and this making will always constitute an infringement. Transferring an e-book in the context of a sale constitutes copying the copyrighted content, also an infringement. Planting a genetically modified seed purchased in the aftermarket constitutes an unauthorized making, or infringement of the patent. Although there have been no published cases about 3D printing as of this writing, a similar analysis could apply to that technology, since transfers of digitized design and digitized personal property may entail copying of the underlying code protected by copyright and patent.

By preventing transfers of a digital work or by connecting protected works to specific matching platforms, ${ }^{101}$ the intellectual property owner can limit uses of a work, including distribution. Such measures are very strong if the technological restriction cannot be worked around. Since the restriction itself might be subject to intellectual property protection (e.g. copyrighted software), the purchaser would be engaging in infringement by even attempting to work around the protection. In this way, technological measures provide a relatively fool-proof way to prevent resale or other uses of a protected work.

As we discussed in the previous section, the exhaustion doctrine needs to be reformed to deal with digital technologies. Two other possible legal limitations on technology protection measures are digital exhaustion and competition law-based limits on such measures. Such reforms would also be necessary to counter technology protection measures. The CJEU provides a model for reforming exhaustion in its 2012 UsedSoft decision. Although mentioned in the previous section, we return to it here as the decision provides a useful compass for charting the future direction of exhaustion. At issue in the case was a business model of selling used software licenses. Oracle licensed access to its online software to customers worldwide. The license granted the customer

"the right to store a copy of the program permanently on server and to allow up to 25 users to access it by downloading it to the main memory of their work-station computers. The license agreement gave the consumer a nontransferable user right for an unlimited period, exclusively for its internal business purposes."

100 Id.

101 Matching platforms would include operating systems on which applications run or complementary products such as cartridges for printers, openers for garage doors, or the classic blades for razors. See e.g. Jonathan M. Barnett, 'The Host's Dilemma: Strategic Forfeiture in Platform Markets for Informational Goods', Harvard Law Review, 2011, p. 1864. 
Licensees would sell used licenses to UsedSoft, a vendor that would resell these licenses to other users. Oracle objected to this practice, claiming a violation of copyright. According to Professor Vincenzo Franceschelli,

"What is new [in the UsedSoft case] is that the principle of exhaustion is applied and applicable to an immaterial copyrighted work - a software program - where the first sale was made on the Internet." ${ }^{\text {102 }}$

Equally valuable is the CJEU's discussion of what constitutes a sale of software, a determination that belies the characterization of the transaction between Oracle and its customers as a license. "A sale," according to the Court, "is an agreement by which a person, in return for payment, transfers to another person his rights of ownership in an item of tangible or intangible property belonging to him."103 There are two elements that make a transaction a sale: "(a) the rightholder receives a payment in compensation for the granting of an unlimited usage right and (b) a transfer of ownership takes place." 104 In the UsedSoft case, the payment and transfer to the client's server satisfied these requirements.

What the UsedSoft ruling suggests is the application of the exhaustion doctrine as a limit on technological protection measures that restrict transfer of a software (and possibly other immaterial goods) after a first sale. How this limitation evolves is a critical question. One direction is to use exhaustion as a policing mechanism to restrict misuse and expansive application of technological protection. Another is to tailor the legal standard to specific technological features. For example, one legal rule may invoke exhaustion only after deletion upon transfer of the original copy of the work, as presented in the US Department of Commerce White Paper. ${ }^{105}$ However, such a 'move and delete' technology is a complex one, requiring a means to distinguish between devices of the purchaser and between the devices of the purchaser and a repurchaser. Another possible, if cumbersome, rule is to allow resale of digital goods if done in conjunction with the sale of the hardware. For example, a purchaser of an electronic book can sell that e-book only along with the reader on which the book is stored. Although this rule would be attractive to manufacturers of readers, as it would promote sales, such a rule may not promote an active market for reselling digital goods. The rule, by requiring physical hardware to accompany the sale of the intangible, seems too narrowly wedded to the traditional personal property roots of exhaustion rather than adapting to the modern realities of digital goods markets.

Digital exhaustion seems less likely to emerge in the United States. A key obstacle is the inapplicability of exhaustion to the right to copy (under copyright) and the right to make (under patent). Although a copy of the digital work was

102 Vincenzo Francheschelli, “To What Extent Does the Principle of Exhaustion of IP Rights Apply to the On-Line Industry?', International League of Competition Law, 2014, p. 15.

103 Id. p. 14.

104 Id.

105 See The Department of Commerce Internet Policy Task Force, White Paper on Remixes, First Sale, and Statutory Damages (January 2016) and our discussion above. 
made by the repurchaser in both ReDigi and UsedSoft, the US court ruled that there was no exhaustion while the CJEU found exhaustion. Technological protection measures therefore would preclude a finding of exhaustion in the US since circumventing the measures and reproducing the protected content would infringe the intellectual property owners' right to copy or to make. Currently, the CJEU adopts a more pragmatic approach based on a need for parity between digital and physical goods, while the US takes a more legalistic approach based on the rights of the intellectual property owner.

Some scholars, ${ }^{106}$ however, have cited the US case Kipling v. G.P. Putnam's Sons ${ }^{107}$ as permitting exhaustion even when a work has been copied. Although a case from the pre-digital age, this precedent from 1903 has relevance for technology protection measures and is worthy of discussion. A distributor bought unbound copies of Kipling's books from the publisher and then rebound separate volumes into one. Kipling, the copyright owner, claimed copyright infringement, but the court found for the distributor. Nothing in the contemporary Copyright Act prohibited the purchaser from binding the copyrighted sheets, according to the court. Kipling relied upon a supposed agreement with the publisher not to sell the unbound sheets. But the court concluded:

"There is nothing in the law [...] which prohibits the owner of a copyright from selling unbound books, if he desires to do so, and what he may do, his agent or license may do also. [...] If such as provision [prohibiting the sale of unbound sheets] were present the plaintiff's remedy would be an action against the publishers for breach of contract." ${ }^{\text {108 }}$

Two points are relevant from this pre-digital case for digital exhaustion. The first is the court's construction of the purchaser's right to make a different version of the copyrighted work after the sale. The recognition of such a right shows that exhaustion may go beyond the narrow right to redistribute. Second, any restrictions on the distribution are a matter of contract, rather than copyright, a result consistent with the application of exhaustion. This case is relevant because it potentially extends the exhaustion doctrine beyond the right to distribute to include other rights such as the right to copy. But, if a court adopted the legalistic approach we saw in ReDigi, such a court would point out that the purchaser in Kipling did not make a copy of the work, but rather took the unbound sheets containing copies of the expression and bound them in a new form. Such acts may implicate the copyright owner's adaptation right, but not the right to copy. In conclusion, the Kipling case is relevant even though it does not fully resolve the digital exhaustion issue. 


\section{Critical Remarks on the Opinion and the Judgment - Reforms Needed!}

We have seen in the previous Section that, on the one hand, the license versus sale dichotomy, the clash of economic rights (distribution versus making available to the public) and the existence of workable forward-and-delete technologies leave considerable space for progressive thinking. On the other hand, the most important copyright norms speak against (a general) digital exhaustion doctrine. In light of these findings, it is of no surprise that both the opinion and the judgment voted against Tom Kabinet.

Such doctrinally safe (or defensive) outcomes do not seem to push modern copyright law towards the proper direction. First, we shall demonstrate that the judgment and the more balanced and more nuanced opinion include logically, practically and theoretically flawed points. Second, we shall re-evaluate the judgment and the opinion in the light of various fundamental policy considerations underlying the exhaustion doctrine. We believe that the only viable solution to the challenges of digital exhaustion requires reformatory, constructive thinking rather than a doctrinal, rigid interpretation of the law. Time has come to reimagine the concept of exhaustion.

\subsection{Five Critical Notes on the Judgment and the Opinion}

Several researchers thought that the judgment settled the tensions surrounding digital exhaustion. ${ }^{109}$ We disagree and believe that the judgment and the opinion include several notable inconsistencies.

First, the judgment and the opinion are flawed in classifying Oracle's original contract in UsedSoft. Both documents expressly refer to the 'sale' of the relevant computer program. ${ }^{110}$ In Tom Kabinet, the CJEU paid no attention to the practical reasons why Oracle's agreement was declared to be a sale. ${ }^{111}$ The Advocate General noted that such broad interpretation to the concept of sale regarding computer programs was necessary to guarantee that the effectiveness of the exhaustion doctrine is not undermined by the different legal consequences attached to the material and immaterial supply of copies. ${ }^{112}$ None of these options are correct or relevant. As mentioned earlier, the CJEU confirmed that licenses may be 'transformed' to sales contracts under certain circumstances. ${ }^{113}$ Neither the Advocate General, nor the CJEU criticized or overruled this legal argument, and the online supply of e-books fulfils the doctrinal requirements of

109 Linda Kuschel, 'Zur urheberrechtlichen Einordnung des Weiterverkaufs digitaler Werkexemplare Anmerkung zu EuGH, Urteil vom 19.12.2019 - C-263/18 - NUV u. a./Tom Kabinet Internet u. a. (ZUM 2020, 129)', Zeitschrift für Urheber- und Medienrecht, 2020/2, p. 138.

110 E.g. Case C-263/18, AG Opinion, para. 59; Case C-263/18, Tom Kabinet, para. 57. The Advocate General was more cautious in this regard, as he used the term 'supply' quite frequently (and more often than sale).

111 Maybe para. 57 of the judgment wanted to clarify the reasons behind this 'transformation' of a license into a sale contract, however, the theory of functional equivalence had a totally different relevance in the original UsedSoft ruling.

112 Case C-263/18, AG Opinion, para. 59.

113 C-128/11, UsedSoft, para. 49. 
the CJEU's UsedSoft standard. Such 'transformation' of the contracts and the relevant economic rights seems entirely valid and applicable to the supply of ebooks as well.

Second, the CJEU partially misconstrued the theory of functional equivalence. Both the Advocate General and the CJEU correctly stressed that the material and immaterial supply of copies of software are functionally similar, as the copy shall be installed, and hence the source of the file(s) might be economically and materially irrelevant. ${ }^{114}$ The CJEU, however, unnecessarily extended the scope of the functional equivalence theory by reference to the nondeterioration of digital copies. The Court treated the files as perfect substitutes to the original copies, which therefore pose an economic danger to the original market of rights holders. ${ }^{115}$ Such arguments hold true for software as well, but more importantly - they are independent from the functional equivalence theory. They rather represent relevant policy arguments. This mistake made by the CJEU is directly documented by the Court itself. The Grand Chamber refers to para. 89 of the Advocate General's opinion, which was located in the Advocate General's policy considerations.

Third, the CJEU has further important rulings other than the ones that the Advocate General analyzed. Indeed, Art \& Allposters is significant for the proper interpretation of 'new copies' made of original artworks; ${ }^{116}$ Ranks and Vasil̨evičs correctly excluded illegal back-up copies from the scope of exhaustion; ${ }^{117}$ Nintendo is relevant with respect to mixed subject matters (e.g. computer games that include software elements and literary/musical works as well); ${ }^{118}$ European Commission $v$. France concluded from a tax law perspective that the supply of ebooks represents service rather than sale; ${ }^{119}$ and a reference to/analysis of Renckhoff would support the CJEU in refuting the applicability of the exhaustion doctrine to the making available to the public right. ${ }^{120}$ Taking these rulings into account would most probably not change the outcome of Tom Kabinet. The deep divergence of case-law highlights, however, the urgent need for the statutory or judicial clarification of the field.

AG Szpunar was of the opinion that the complexity and inconsistency of the CJEU's case-law does not justify the judicial recognition of a digital exhaustion doctrine. ${ }^{121}$ Leaving the solution to the legislation may be the most reasonable solution (at least in typical Continental European countries). At the same time,

114 Case C-263/18, AG Opinion, para. 60; Case C-263/18, Tom Kabinet, para. 57.

115 Id. para. 58.

116 Judgment of 22 January 2015, Case C-419/13, Art \& Allposters International, ECLI:EU:C:2015:27. This was the only ruling that the CJEU referred to in its judgment. See Case C-263/18, Tom Kabinet, para. 52.

117 Judgment of 12 October 2016, Case C-166/15, Ranks and Vasil̦evičs, ECLI:EU:C:2016:762.

118 Case C-355/12, Nintendo and others.

119 Judgment of 5 March 2015, Case C-479/13, Commission v. France, ECLI:EU:C:2015:141.

120 Judgment of 7 August 2018, Case C-161/17, Renckhoff, ECLI:EU:C:2018:63.

121 Case C-263/18, AG Opinion, para. 78. 
the CJEU was often criticized for its 'judicial activism', ${ }^{122}$ that is, for those rulings that contributed to the pragmatic development of EU (copyright) law. Such activism was detected both in the presence and in the lack of relevant international norms. Such a notable example is the CJEU's 'new public theory'. The 'new' element of the communication to the public right lacks all relevant international law background. ${ }^{123}$ To put it differently: the CJEU is not barred from ruling against the (international) copyright status quo, if it wants to do so. (Some might declare the UsedSoft ruling as a perfect example for this practice.) At the same time, in the lack of clear consistency, it is not easy to understand when the CJEU will exercise, or refrain from activism. According to Harri Kalimo et al.,

"the Court gives only a [very] limited voice to those other discourses that would have supported the legal arguments and values that were contrary to the Court's judicial decision. [...] We observed a clear structural bias favouring the voices that supported the Court's own argumentation." 124

Such a bias is clearly evidenced by the (almost) full disregard of policy considerations by the CJEU in Tom Kabinet; the lack of coherent interpretation of the relevant terminology [e.g. 'copy' or '(first) sale'] of EU law; ${ }^{125}$ or the highly questionable interpretation of 'public' with respect to members of the reading club. ${ }^{126}$

Fourth, the CJEU may have completely misunderstood Tom Kabinet's business model. The CJEU noted that

"In the present case [...] any interested person can become a member of the reading club, and to the fact that there is no technical measure on that club's platform ensuring that (i) only one copy of a work may be downloaded in the period during which the user of a work actually has access to the work and (ii) after that period has expired, the downloaded copy can no longer be used by that user [...], it must be concluded that the number of persons who may

122 Cf. Mark Dawson et al. (eds.), Judicial Activism at the European Court of Justice, Edward Elgar, Cheltenham, 2013; Gunnar Beck, 'Judicial Activism in the Court of Justice of the EU', University of Queensland Law Journal, 2017/2, pp. 333-353.

123 The CJEU's rhetoric in Tom Kabinet regarding the obligation to follow international standards is a bit sarcastic. In its judgment, the CJEU noted that "EU legislation must, moreover, so far as possible, be interpreted in a manner that is consistent with international law, in particular where its provisions are intended specifically to give effect to an international agreement concluded by the European Union (judgments of 7 December 2006, SGAE, C-306/05, EU:C:2006:764, paragraph 35; [...])". See Case C-263/18, Tom Kabinet, para. 38. It was exactly SGAE that introduced the 'new public theory' in the lack of any supportive international source.

124 Harri Kalimo et al., 'Of Values and Legitimacy - Discourse Analytical Insights on the Copyright Case Law of the Court of Justice of the European Union', Modern Law Review, 2018/2, p. 304.

125 Christoph Peter, 'Urheberrechtliche Erschöpfung bei digitalen Gütern', Zeitschrift für Urheberund Medienrecht, 2019/6, p. 500.

126 Cf. Ohly 2020, pp. 184-185; Homar 2020, pp. 30-31. 
have access, at the same time or in succession, to the same work via that platform is substantial." 127

Such a finding is problematic, as the referring court summarized the facts of the case to the direct opposite. ${ }^{128}$ Imagine that - under the real facts of the case - the CJEU incorrectly held the members of the reading club to be the 'public', and now direct your attention on the other element of the CJEU's argumentation: "having regard to the fact [...] that there is no technical measure on that club's platform". Imagine that Tom Kabinet (or any other platform) applies technical measures that guarantee the access of a single copy of a work by one end-user at a given time. (We could call such a measure an effective forward-and-delete technology.) Would the CJEU's syllogism mean that digital exhaustion is acceptable in the latter situation? ${ }^{129}$ Or - even worse - would that mean that the CJEU believes there is no 'public' in the latter situation, and so the making available to the public right is 'quasi exhausted'? It is truly hard to decide which of these options is more favorable from a doctrinal or policy perspective.

Fifth, as the CJEU failed to answer the remaining questions of the referring court, an important issue remained unanswered. The referring court requested clarification whether the resale of the device containing the digital files fits into the concept of exhaustion. We agree with Phillip Homar that such resales shall not be prohibited by the EU law. ${ }^{130}$

\subsection{Seven Policy Considerations in Favor of Digital Exhaustion}

First, following Tom Kabinet, the doctrine of exhaustion can practically lose its relevance in the online environment. Is such a hollowing out of the doctrine really in the interest of the society ${ }^{131}$ Wouldn't it be wiser to force/keep competition between the rights holders and newcomers in order to guarantee the best available services for the benefit of society as a whole? Indeed, AG Szpunar expressly noted that the holding in $V O B$ (the acceptance of e-lending, partially based on a de facto acceptance of digital exhaustion) loses its significance if the CJEU votes against digital exhaustion. ${ }^{132}$ The CJEU was undeterred by such a consequence.

Second, Yves Gaubiac noted as early as 2000 that the dematerialization of works and the advancement of online uses make it necessary to appropriately categorize the supply of digital contents via the Internet. The importance of such

127 Case C-263/18, Tom Kabinet, para. 69.

128 Homar 2020, pp. 29-30.

129 Cf. Morgan et al. 2020, p. 237; Eleonora Rosati, 'Round-up of CJEU Copyright Decisions in 2019', Journal of Intellectual Property Law \& Practice, 2020/4, p. 268; Caterina Sganga, 'Is the Digital Exhaustion Debate Really Exhausted? Some Afterthoughts on the Grand Chamber Decision in Tom Kabinet (C-263/18)', Kluwer Copyright Blog, 19 May 2020, at http://copyright blog.kluweriplaw.com/2020/05/19/is-the-digital-exhaustion-debate-really-exhausted-someafterthoughts-on-the-grand-chamber-decision-in-tom-kabinet-c-263-18/.

130 Homar 2020, pp. 32-33.

131 Ohly 2020, pp. 186-187; Homar 2020, p. 29.

132 Case C-263/18, AG Opinion, paras. 71-72. 
categorization is great, as it can directly affect the fate of the doctrine of exhaustion. ${ }^{133}$ The same opinion was expressed by Advocate General Kokott in FAPL. ${ }^{134}$ The CJEU seemed unable to sidestep the services versus goods dichotomy. Admittedly, as indicated above, the existing norms did not introduce a 'hybrid model' of online contracts. A consumer/end-user-oriented approach would, however, be the most reasonable and balanced solution to the stalemate of the services versus goods dichotomy.

Third, AG Szpunar concluded that

"Although there are strong reasons for recognising the rule of exhaustion of the right of distribution in the case of downloading, other reasons, however, at least as strong, are opposed to such recognition. Thus, the weighing up of the various interests involved does not cause the balance to come down in a different way from that which follows from the letter of the provisions in force." 135

No doubt, balancing various interests is a troublesome and challenging task - and therefore subjective as well. With full respect to AG Szpunar's detailed analysis of the policy considerations, we disagree with his conclusion. If we compare the pros and cons of digital exhaustion, much more relevant arguments speak in favor of the generalized application of the doctrine of exhaustion. E.g. the three-step test (especially its third prong related to the economic effects of any subsequent uses) does not apply to exhaustion; the cheaper nature of downstream commerce allows for easier access to culture and for the reinvestment of remaining resources to the economy as a whole; a digital exhaustion doctrine is in full compliance with the logic of the reward theory; voluntary remuneration systems (like the one Tom Kabinet or ReDigi envisaged) may further ease tensions. De facto or de jure monopolies are not supported by copyright (and competition) law, and therefore, the preservation of the status quo by hindering external innovations is truly unwarranted. History also evidenced that downstream commerce did not quash 'original' markets. To the contrary, rights holders modernized their business models in the wake of new technological or social challenges. ${ }^{136}$ We believe that the fear of technological superiority of digital files over analogue ones (which is not an absolute truth), the negative commercial consequences or the complicated control over file exchanges do not trump the arguments listed above. ${ }^{137}$

Fourth, the legal distinction between the online supply of software and other subject matter necessarily leads to tensions with other legal norms, especially consumer protection law. As we have seen above, the EU's directive on consumer

133 Yves Gaubiac, 'The Exhaustion of Rights in the Analogue and Digital Environment', Copyright Bulletin, 2002/4, p. 10.

134 Joined Cases C-403/08 and C-429/08, Football Association Premier League and others, Opinion of Advocate General Kokott, delivered on 3 February 2011, ECLI:EU:C:2011:43, paras. 184-188.

135 Case C-263/18, AG Opinion, para. 97.

136 See Mezei 2018, pp. 148-154.

137 For further economic arguments see Sganga 2018, pp. 230-232. 
protection treats the online supply of contents equally - irrespective of the copyright status of the works. Consumers have a valid claim that their purchases be treated on an equal footing - and that the doctrine of exhaustion be applied to lawfully acquired copies of subject matter other than software, too. This argument is accepted by a recent trial court ruling in France. In Union Fédérale des Consommateurs, an association representing consumers' interests successfully claimed that a leading computer games producer's strict limitation to the resale of lawfully acquired computer games runs counter to French consumer protection laws. The French court also held that such computer games (in compliance with the CJEU's Nintendo ruling) fall under the scope of the InfoSoc-Directive as mixed works, rather than the Software Directive. Consequently, consumers/end-users shall be allowed to dispose of the copies they downloaded against payment from the software corporation's website under the doctrine of exhaustion. ${ }^{138}$ If this ruling will be confirmed by the court of appeals, it can serve as a solid ground for a 'consumer law based doctrine of exhaustion' on a European level too.

Fifth, the CJEU's treatment of e-books as service rather than goods in EC v. France, and the reliance on the making available to the public rather than on the distribution right in Tom Kabinet does not only lead to the exclusion of e-books (and almost all other subject matters) from the scope of exhaustion, but also narrows down end-users' (lawful acquirers') limitations and exceptions under the InfoSoc-Directive. As Member States have implemented this directive with notable differences, it is possible that nationals of various EU countries might have to rely on limitations and exceptions under significantly different circumstances.

Sixth, AG Szpunar echoed a recurring argument in his opinion, when he declared exhaustion obsolete in the age of streaming and online subscriptions. ${ }^{139}$ No doubt, online consumption tends to be more access based rather than 'ownership based'. Nevertheless, a significant amount of content is still available for download and purchase; and that is true for almost all sectors of the copyright industry. Consequently, the need to address the resale of lawfully acquired copies of protected subject matter cannot be ignored.

Finally, world IP policy leaders may need to get ready to introduce 'emergency IP norms' at some point. The Coronavirus SARS-CoV-2 pandemic (COVID-19), and the extensive legal, social and economic limitations imposed by governments shed light on the vulnerability of the existing IP order. COVID-19 will not only lead to significant (and longstanding) social distancing, ${ }^{140}$ but will also affect remote education, media consumption and the copyright industry's existing business models (especially related to the production and dissemination of

138 Union Fédérale des Consommateurs - Que Choisir v. S.A.R.L. Valve, Tribunal de Grande Instance de Paris, $\mathrm{N}^{\circ}$ RG 16/01008.

139 Case C-263/18, A G Opinion, para. 95.

140 Gideon Lichfield, 'We're Not Going Back to Normal', MIT Technology Review, 17 March 2020, at www.technologyreview.com/s/615370/coronavirus-pandemic-social-distancing-18-months/. 
content). ${ }^{141}$ The growing need for online consumption and the still existing interests of consumers towards ownership may also support the application of the exhaustion doctrine to copies supplied via the Internet. No doubt, only extensive empirical research can prove whether a digital exhaustion doctrine would be advisable under such an 'emergency IP regime'.

141 Brooks Barnes \& Nicole Sperling, 'Studio's Movies in Theaters Will Be Offered for In-Home Rental', The New York Times, 16 March 2020, at www.nytimes.com/2020/03/16/business/media/ coronavirus-universal-home-movies.html; Alexandra Alter, 'The World of Books Braces for a Newly Ominous Future', The New York Times, 16 March 2020, at www.nytimes.com/2020/03/16/ books/coronavirus-impact-publishing-industry-booksellers-authors.html. 